\title{
Utilization of endogenous and dietary urea in the large intestine of the mature horse
}

\author{
BY R. G. MARTIN ${ }^{*}$, N.P. MCMENIMAN¹, B. W. NORTON ${ }^{2}$ \\ AND K. F. DOWSETT ${ }^{1}$ \\ ${ }^{1}$ Department of Farm Animal Medicine and Production and ${ }^{2}$ Department of Agriculture, \\ University of Queensland, St Lucia, Queensland, Australia, 4072
}

(Received 27 January 1995 - Revised 20 November 1995 - Accepted 12 December 1995)

\begin{abstract}
The dynamics of $\mathrm{N}$ metabolism in mature horses were investigated when they were fed on a low- $\mathrm{N}$ diet or the same diet supplemented with sufficient urea or soyabean meal to meet their theoretical $\mathbf{N}$ requirements. There were no differences in DM, organic matter or neutral-detergent-fibre digestibilities for the three diets. $\mathbf{N}$ digestibilities and digestible- $\mathbf{N}$ intakes were similar for the urea- and soyabeansupplemented diets and very low for the low- $\mathrm{N}$ diet. For all three diets plasma urea was degraded in the digestive tract to $\mathrm{NH}_{3}$ which was utilized by the bacterial population as a $\mathrm{N}$ source. $\mathrm{NH}_{3}$ was absorbed from the large intestine into the blood and converted to urea. $\mathrm{NH}_{3}$ was also incorporated into plasma proteins. The horses fed on the low- $\mathrm{N}$ diet degraded a greater proportion of endogenous urea in the digestive tract than did horses fed on the urea- or soyabean-supplemented diets. However, the horses fed on the urea diet had the highest degradation rate of urea. The quantity of urea degraded in the digestive tract of horses fed on the urea-supplemented and the low- $\mathrm{N}$ diets could not compensate for a lack of dietary crude protein in these diets. The horses were in a negative $\mathbf{N}$ balance when fed on the low- $\mathrm{N}$ and urea-supplemented diets and a positive $\mathbf{N}$ balance when fed on the soyabean-supplemented diet. Dietary urea supplementation did not benefit the horses.
\end{abstract}

Urea: Nitrogen metabolism: Horse

There is some debate concerning the horse's ability to utilize urea. At present it is not known if dietary urea supplementation has a place in the horse industry, particularly in the case of mature horses grazing poor quality pastures. It has been shown that endogenous urea is degraded in the large intestine and the proportion of endogenous urea degraded increases with low-protein diets (Houpt \& Houpt, 1971; Prior et al. 1974). These results indicate that horses utilize some endogenous urea and therefore it is possible that supplementary urea may be of nutritional benefit.

The aim of the present experiment was to investigate the utilization of urea in the large intestine of the mature horse and to provide further information on the dynamics of $\mathbf{N}$ metabolism in horses fed on low- and adequate-protein diets.

\section{METHODS}

\section{Animals}

Three adult geldings, two Standardbreds and one Arabian (average weight $400 \mathrm{~kg}$ ), aged between 5 and 7 years were each surgically fitted with two polyvinyl chloride (PVC) cannulas which had an outside diameter of $15 \mathrm{~mm}$ and an internal diameter of $10 \mathrm{~mm}$. One

* Present address: Australian Quarantine and Inspection Service, Development and Evaluation Division, Department of Primary Industries and Energy, GPO Box 858, Canberra ACT Australia 2601. 
Table 1. Composition of diets $(\mathrm{g} / \mathrm{kg} \mathrm{DM})$ fed during each experimental period

\begin{tabular}{lccc}
\hline & & \multicolumn{3}{c}{ Diet } \\
\cline { 2 - 4 } Ingredient & LN & LNU & LNS \\
\hline Barley straw & $762 \cdot 7$ & $747 \cdot 6$ & $672 \cdot 8$ \\
Molasses & $204 \cdot 9$ & $200 \cdot 5$ & $182 \cdot 2$ \\
Urea & 0 & $20 \cdot 3$ & 0 \\
Soyabean meal & 0 & 0 & $116 \cdot 3$ \\
Vegetable oil & $19 \cdot 7$ & $19 \cdot 2$ & $17 \cdot 4$ \\
Iodized salt & $4 \cdot 2$ & $4 \cdot 1$ & 3.8 \\
Dicalcium phosphate & $7 \cdot 1$ & 6.9 & $6 \cdot 3$ \\
Vitamin-mineral mix* & $1 \cdot 4$ & 1.4 & 1.2 \\
Nitrogen & 4.4 & 13.7 & $13 \cdot 3$ \\
\hline \hline
\end{tabular}

LN, low nitrogen; LNU, low nitrogen + urea; LNS, low nitrogen + soyabean meal.

* Each $\mathrm{kg}$ of mix contained $(\mathrm{g})$ : retinol acetate 4.5 , cholecalciferol 0.8 , riboflavin 4 , cyanocobalamin 0.011 , $\alpha$-tocopherol 10, $\mathrm{Ca} \mathrm{2,} \mathrm{Cu} 1 \cdot 25 ; \mathrm{Fe} \mathrm{6,} \mathrm{Mn} \mathrm{4,} \mathrm{Zn} \mathrm{5,} \mathrm{NaCl} 30, \mathrm{Co} \mathrm{0.025,} \mathrm{I,} \mathrm{0.1,} \mathrm{Mg} \mathrm{0.5.}$

cannula was placed in the right ventral colon (just past the caeco-colic junction) and the other in the right dorsal colon (approximately $100 \mathrm{~mm}$ before the small colon) using a method similar to that described by Simmons \& Ford (1988).

\section{Diets and experimental design}

At 2 months after the surgery the horses were individually stabled and fed on one of three diets in a $3 \times 3$ Latin square design. Within each of the three experimental periods there were three $5 \mathrm{~d}$ collection periods. The diets consisted of a low-N $\operatorname{diet}(\operatorname{diet} \mathrm{LN})$, a low-N diet supplemented with adequate urea to meet the theoretical $\mathrm{N}$ requirements (National Research Council (NRC), 1978) of each horse (diet LNU), and a low-N diet supplemented with adequate soyabean meal to meet the $\mathrm{N}$ requirements of each horse (diet LNS). The diets were designed to meet the theoretical digestible energy requirements (NRC, 1978) of each horse. The composition of the diets is listed in Table 1.

Each horse was fed on its respective diet for an adaptation period of 3 weeks before each of the three experimental periods. For $2 \mathrm{~d}$ before each of these periods and throughout the experimental periods the horses were given one sixth of their respective diet at intervals of $4 \mathrm{~h}$. Feed intake and total output of faeces and urine of each horse were measured for each $5 \mathrm{~d}$ collection period. This resulted in three measurements of digestibility for each horse for each experimental period. Samples of the dietary ingredients and the feed refusals from each horse were collected daily for each $5 \mathrm{~d}$ collection period, weighed and stored at $-20^{\circ}$.

The horses were restrained in individual metabolism stalls during the three $5 \mathrm{~d}$ collection periods of each experimental period, except for $0.5 \mathrm{~h}$ each day when they were given mild exercise on a treadmill. Urine-collecting harnesses were fitted to the horses. The urine produced each day was collected into 20 -litre containers to which $200 \mathrm{ml} 12 \mathrm{M}-\mathrm{HCl}$ had been added. Faeces were voided onto plastic sheets placed behind the horses. Each horse was weighed at the beginning and end of each $15 \mathrm{~d}$ experimental period.

\section{Experimental procedures}

During the $15 \mathrm{~d}$ collection period of each experimental feeding period there were three isotope programmes; each isotope programme contained a $5 \mathrm{~d}$ collection period. At $1 \mathrm{~h}$ before each period of isotope administration a 15-gauge teflon indwelling catheter was aseptically inserted into the jugular vein of each horse and sutured in place. 
For the first isotope programme a $55 \mathrm{ml}$ aqueous solution containing $\left[{ }^{15} \mathrm{~N}_{2}\right]$ urea $(250 \mathrm{mg}$ $99 \%$ enriched $\left.{ }^{16} \mathrm{~N}\right)$ and ${ }^{51} \mathrm{CrEDTA}(9 \cdot 25 \mathrm{MBq})$ was administered via a nasogastric tube into the stomach. The intragastric dose of $\left[{ }^{15} \mathrm{~N}\right]$ urea and ${ }^{51} \mathrm{CrEDTA}$ was administered only to those horses fed on diet LNU.

In the second programme a single intravenous injection of $\left[{ }^{15} \mathrm{~N}_{2}\right]$ urea $(250 \mathrm{mg} 99 \%$ enriched ${ }^{15} \mathrm{~N}$ ) in $5 \mathrm{ml}$ isotonic saline was administered to each horse (diets LN, LNU and LNS). Additionally, in the second and third experimental periods a $50 \mathrm{ml}$ solution containing $9.25 \mathrm{MBq}{ }^{51} \mathrm{CrEDTA}$ was administered into the right dorsal colon of each horse.

In the third isotope programme an aqueous solution containing $4 \mathrm{ml}\left({ }^{15} \mathrm{NH}_{4}\right)_{2} \mathrm{SO}_{4}$ (200 mg 99.3\% enriched ${ }^{15} \mathrm{~N}$ ) and $50 \mathrm{ml}{ }^{51} \mathrm{CrEDTA}(9 \cdot 25 \mathrm{MBq})$ was administered through the PVC cannula into the right ventral colon of each horse (diets LN, LNU and LNS).

\section{Sampling procedures and preparation of samples}

Jugular blood samples $(20 \mathrm{ml})$ were obtained from each horse before each isotope administration and then at $0 \cdot 5,1,2,4,6,8,10,12,16,20,24,30,36,48,60$ and $72 \mathrm{~h}$ after administration. The heparinized blood samples were centrifuged at $1510 \mathrm{~g}$ for $10 \mathrm{~min}$ and the plasma was stored at $-20^{\circ}$.

Samples of ventral and dorsal colonic fluid $(70 \mathrm{ml})$ were collected from each horse before each tracer administration and at $0 \cdot 5,1,2,3,4,5,6,7,8,9,10,12,14,16,20,24,30,36$, 48,60 and $72 \mathrm{~h}$ after administration. Each sample was obtained by suction through a plastic tube directed into the colon and then passed through a fine nylon gauze to remove large particulate matter. The $\mathrm{pH}$ of each sample was determined.

The colonic fluid samples were centrifuged at $1000 \mathrm{~g}$ for $2 \mathrm{~min}$ to separate plant material. The supernatant fraction was decanted and then centrifuged at $19000 \mathrm{~g}$ for $20 \mathrm{~min}$. Duplicate samples of supernatant fraction $(2 \mathrm{ml})$ were pipetted into isotope-counting tubes for ${ }^{51} \mathrm{Cr}$ analysis. A further $5 \mathrm{ml}$ supernatant fraction was added to an equal volume of $0.2 \mathrm{M}-\mathrm{HCl}$ and stored at $-20^{\circ}$ for subsequent ${ }^{15} \mathrm{~N}$ analysis along with the remaining supernatant fraction for subsequent volatile fatty acid (VFA) analysis. Bacterial samples were obtained by resuspending the precipitated solid material in isotonic saline and centrifuging again for $10 \mathrm{~min}$ at $19000 \mathrm{~g}$. The supernatant fraction was discarded and the bacterial pellet was resuspended in $10 \mathrm{ml}$ isotonic saline and stored at $-20^{\circ}$. The bacterial samples obtained were examined microscopically and found to be free of plant material.

Faeces and urine produced by each horse were weighed daily during each $5 \mathrm{~d}$ isotope programme. Each day 0.1 of each horse's daily faecal output, together with 0.01 of the daily urinary output were collected and stored at $-20^{\circ}$.

\section{Analytical procedures}

Plasma urea- $\mathrm{N}$ and urea- $\mathrm{N}$ concentrations in urine were determined spectrophotometrically using an enzymic method (Boehringer Mannheim, Castle Hill, NSW, Australia).

The dietary ingredients, feed refusals and faeces were analysed for DM and organic matter (OM) by the methods described by the Association of Official Agricultural Chemists (AOAC) (1965) and the gross energy content was determined by bomb calorimetry. Neutral-detergent fibre (NDF) was estimated using the method of Goering \& Van Soest (1970). Total $\mathrm{N}$ was determined on the dietary ingredients, feed refusals, faeces and urine by the Kjeldahl procedure (AOAC, 1965).

Total VFA concentrations and the molar proportions were determined on colonic samples by GLC (Hewlett Packard 8530A Gas Chromatograph and Hewlett Packard 
18850A Gas Chromatograph terminal, Palo Alto, CA, USA). Samples were pooled so that only one ventral and one dorsal colonic sample were analysed for each isotope programme for each horse fed on each diet. Colonic samples were prepared for VFA analysis using a similar method to that described by Cottyn \& Boucque (1968).

The $\mathrm{N}$ in the colonic, microbial, faecal and urinary samples was converted to $\left(\mathrm{NH}_{4}\right)_{2} \mathrm{SO}_{4}$ as required for ${ }^{15} \mathrm{~N}$ analysis by the method described by Nolan \& Leng (1972).

$\mathrm{NH}_{3}$ derived from plasma urea was obtained after precipitating the protein from the plasma with TCA $(100 \mathrm{~g} / 1)$. The supernatant fraction was then passed through an ionexchange column which bound the amino acids (Mills et al. 1981). The eluate was collected and evaporated to dryness at $70^{\circ}$, then dissolved in distilled water, digested and distilled for $\mathrm{NH}_{3}$ as described by Nolan \& Leng (1972).

The plasma protein precipitates obtained by the above procedure from samples collected $36 \mathrm{~h}$ after $\left({ }^{15} \mathrm{NH}_{4}\right)_{2} \mathrm{SO}_{4}$ administration into the ventral colon (isotope programme 3 ) were digested and the distilled $\mathrm{NH}_{3}$ quantified.

The enrichment of samples with ${ }^{15} \mathrm{~N}$ was determined with a mass spectrometer (Model VG Micromass 622 and Isotope Ratio Mass Spectrometer upgrade, Europa Scientific Ltd, Urmston, Greater Manchester) after converting $\left(\mathrm{NH}_{4}\right)_{2} \mathrm{SO}_{4}$ to $\mathrm{N}_{2}$ gas using sodium hypobromite (Nolan \& Leng, 1972). Abundance of ${ }^{15} \mathrm{~N}$ in the $\mathrm{N}$ in the samples was calculated from the ratio of mass 28 and 29 peaks after correcting for background peaks and air contamination. The total ${ }^{15} \mathrm{~N}$ enrichment of the plasma protein precipitates was not quantified. These samples were analysed for the presence or absence of ${ }^{15} \mathrm{~N}$.

The specific radioactivity of ${ }^{51} \mathrm{CrEDTA}$ in the ventral and dorsal colonic supernatant fractions and urinary samples was determined using a gamma spectrometer (Packard Instrument Co., CT, USA).

\section{Analysis of isotope dilution data}

Right ventral colonic $\mathrm{NH}_{3}-\mathrm{N}$ pool size, total flux rate (total $\mathrm{N}$ entering the colonic pool), irreversible loss rate ( $\mathrm{N}$ irreversibly lost from the colonic pool) and recycling rate of $\mathrm{NH}_{3}$ $\mathrm{N}$ ( $\mathrm{N}$ leaving but returning to the colonic pool) following right ventral colonic administration of $\left({ }^{15} \mathrm{NH}_{4}\right)_{2} \mathrm{SO}_{4}$ were determined using the equations derived from exponential curves as described by White et al. (1969). When fitting the equation to the ${ }^{15} \mathrm{~N}$ enrichment curve of plasma urea- $\mathrm{N}$ following intravenous administration of $\left[{ }^{15} \mathrm{~N}\right]$ urea the first sampling point was disregarded, as it appeared that $\left[{ }^{15} \mathrm{~N}\right]$ urea had not equilibrated in the body at $30 \mathrm{~min}$. The rate of irreversible loss of urea-N from the plasma pool and body urea-N pool size were determined using equations derived from exponential curves. Urea$\mathrm{N}$ degradation rate in the gastrointestinal tract was calculated as the difference between the irreversible loss of urea- $\mathrm{N}$ from plasma and urinary urea- $\mathrm{N}$ excretion.

The area under the ${ }^{15} \mathrm{~N}$ enrichment-with-time curve (AUC) for the primary $\mathrm{N}$ pools for any time period was calculated by integrating equations obtained from fitted curves (Nolan \& Leng, 1972). AUC for secondary $\mathrm{N}$ pools were determined by planimetry. The proportion of $\mathrm{N}$ in any secondary pool derived from a primary pool was calculated from the secondary:primary AUC ratio for the period from 0 to $24 \mathrm{~h}$ after isotope administration.

The rate of $\mathrm{N}$ transfer from plasma urea to ventral colonic $\mathrm{NH}_{3}$ was calculated as the product of the proportion of ventral colonic $\mathrm{NH}_{3}-\mathrm{N}$ derived from plasma urea- $\mathrm{N}$ and the irreversible loss rate of ventral colonic $\mathrm{NH}_{3}-\mathrm{N}$. The rate of $\mathrm{N}$ transfer from ventral colonic $\mathrm{NH}_{3}$ to plasma urea was calculated as the product of the proportion of plasma urea- $\mathrm{N}$ derived from ventral colonic $\mathrm{NH}_{3}-\mathrm{N}$ and the irreversible loss rate of urea-N from plasma (Nolan \& Leng, 1972). 
The proportion of intragastric $\left[{ }^{15} \mathrm{~N}\right]$ urea which was absorbed into the blood over the time period 0 to infinity was determined from the ratio of the AUC of plasma urea-N when the ${ }^{15} \mathrm{~N}$ was administered by the intragastric route to the AUC of plasma urea- $\mathrm{N}$ when it was administered intravenously. The AUC were determined by integration.

\section{Statistical analyses}

The data were analysed with ANOVA considering the individual effects of diet, animal and experimental period and the interactions between these effects. Sequential repeated measures for each of the nine combinations of the Latin square were averaged for each horse for each isotope programme and then within each experimental period before ANOVA. Means were compared using $t$ tests, using standard deviations based on the residual variance. All data obtained from horse 3, diet LNS during the third isotope programme (colonic $\left({ }^{15} \mathrm{NH}_{4}\right)_{2} \mathrm{SO}_{4}$ ), were excluded in calculating means of that group due to a negative $\mathrm{N}$ balance (twice that of the standard deviation of the mean).

Colonic $\mathrm{NH}_{3}$, total VFA concentrations and colonic $\mathrm{pH}$ were analysed using ANOVA as described above but included another factor site (ventral or dorsal colon). As there was no diet $x$ site interaction and site was significantly different, the sites were then analysed separately.

\section{RESULTS}

Digestibility of the diets

DM, OM, NDF and N digestibilities of the three diets are presented in Table 2. The horses, when fed on the LN and LNU diets, were in negative $\mathrm{N}$ balance whereas when they were fed on the LNS diet they were in positive $\mathrm{N}$ balance (Table 2). The horses lost on average $12 \cdot 7$ (range -25 to -3 ) $\mathrm{kg}$ in weight while fed on the LN diet, 13.3 (range -19 to -8 ) $\mathrm{kg}$ while fed on the LNU diet and 4.7 (range -11 to 0 ) $\mathrm{kg}$ while fed on the LNS diet.

\section{Volatile fatty acid concentrations}

Diet did not significantly influence the total VFA concentrations or the molar proportions of VFA in the right ventral or right dorsal colon. However, the total VFA concentration and the molar proportions of acetate, isobutyrate, isovalerate and n-valerate were significantly lower $(P<0.05)$ in the ventral colon than in the dorsal colon. The molar proportions of propionate and n-butyrate were significantly higher $(P<0 \cdot 01)$ in the ventral colon than in the dorsal colon (Table 3).

Single intragastric dose of $\left[{ }^{15} \mathrm{~N}\right]$ urea

Following intragastric dosing the $\left[{ }^{15} \mathrm{~N}\right]$ urea was rapidly absorbed into the blood (Fig. 1) with peak enrichment reached within $2-3 \mathrm{~h}$. The proportion of dietary urea- $\mathrm{N}$ entering plasma urea- $\mathrm{N}$ averaged 90 (SD 12:3, range 76-100) \%.

In the first $24 \mathrm{~h}$ after the intragastric administration of $\left[{ }^{15} \mathrm{~N}\right] \mathrm{urea}, 44$ (SD $3 \cdot 6$ ) $\%$ of the dose was excreted in urinary $\mathrm{N}$ and 1 (SD 0.2 ) \% was excreted in faecal $\mathrm{N}$. Over the $5 \mathrm{~d}$ collection period, 64 (SD 3.9) \% was excreted in urinary $\mathrm{N}$ and 10 (SD 1.0$) \%$ in faecal $\mathrm{N}$. The proportion of dietary urea retained, determined after a single intragastric dose of $\left[{ }^{15} \mathrm{~N}\right]$ urea and $5 \mathrm{~d}$ collection of urine and faeces, was 26 (SD 3.4, range $23-30$ ) \%.

\section{Single intravenous injection of $\left[{ }^{15} \mathrm{~N}\right]$ urea}

An example of the enrichment of plasma urea- $\mathrm{N}$ with time following a single injection of $\left[{ }^{15} \mathrm{~N}\right]$ urea into the blood is presented in Fig. 2 for the diet LNU (horse 3). The $\left[{ }^{15} \mathrm{~N}\right]$ urea 'enrichment with time' curves in plasma were best described by equations with a single 
Table 2. Mean digestibility of nutrients $(\mathrm{g} / \mathrm{g})$ and energy content $(\mathrm{MJ} / \mathrm{kg} \mathrm{DM})$ of each of the three diets and daily nitrogen intake, faecal nitrogen and urinary nitrogen excretion and nitrogen balance $(\mathrm{g} / \mathrm{d})$ of the three horses*

\begin{tabular}{|c|c|c|c|c|}
\hline \multirow[b]{2}{*}{ Item } & \multicolumn{4}{|c|}{ Diet } \\
\hline & $\mathbf{L N}$ & LNU & LNS & SD \\
\hline DM digestibility & 0.52 & 0.52 & 0.53 & 0.020 \\
\hline OM digestibility & $0-51$ & 0.51 & 0.52 & 0.021 \\
\hline NDF digestibility & $0 \cdot 41$ & $0 \cdot 40$ & 0.37 & 0.025 \\
\hline $\mathrm{N}$ digestibility & $0 \cdot 06^{\mathrm{a}}$ & $0.72^{\mathrm{b}}$ & $0.71^{\mathrm{b}}$ & $0 \cdot 018$ \\
\hline DE & $8 \cdot 0$ & $7 \cdot 7$ & $8 \cdot 4$ & 0.35 \\
\hline $\mathrm{N}$ intake & $28 \cdot 2^{a}$ & $95 \cdot 1^{\mathrm{b}}$ & $98 \cdot 2^{\mathrm{b}}$ & $8 \cdot 11$ \\
\hline $\mathrm{N}$ intake $(\%) \dagger$ & 33 & 111 & 115 & - \\
\hline Faecal $\mathrm{N}$ excretion & $26 \cdot 2$ & $26 \cdot 4$ & $28 \cdot 7$ & $2 \cdot 38$ \\
\hline Urinary $\mathrm{N}$ excretion & $17 \cdot 6^{\mathrm{a}}$ & $74 \cdot 4^{b}$ & $56 \cdot 2^{c}$ & $2 \cdot 46$ \\
\hline Digestible $\mathbf{N}$ intake & $2 \cdot 0^{2}$ & $68 \cdot 6^{b}$ & $69 \cdot 5^{b}$ & $5 \cdot 75$ \\
\hline $\mathrm{N}$ balance & $-15 \cdot 6^{\mathrm{a}}$ & $-5 \cdot 7^{\mathrm{a}}$ & $13 \cdot 3^{\mathbf{b}}$ & $5 \cdot 86$ \\
\hline
\end{tabular}

OM, organic matter; NDF, neutral-detergent fibre; DE, digestible energy; LN, low nitrogen; LNU, low nitrogen + urea; LNS, low nitrogen + soyabean meal.

$\mathbf{a}, \mathbf{b}, \boldsymbol{c}$ Mean values within a row with different superscript letters were significantly different $(P<0.05)$.

* For details of diets and procedures, see Table 1 and pp. 374-375.

$\dagger$ Expressed as a percentage of the recommended amount (National Research Council, 1989).

Table 3. Mean total volatile fatty acid (VFA) concentrations (mmol/l) and the molar proportions of $V F A(\%)$ in the right ventral and right dorsal colon of three horses fed on three diets* $^{*}$

\begin{tabular}{lccc}
\hline & & Site & \\
Measurement & Right dorsal colon & SD \\
\cline { 2 - 4 } & Right ventral colon & $75 \cdot 1^{\mathrm{b}}$ & $5 \cdot 77$ \\
Total VFA concentration & $58 \cdot 2^{\mathrm{a}}$ & $78 \cdot 3^{\mathrm{b}}$ & $1 \cdot 68$ \\
Molar percentage & $72 \cdot 4^{\mathrm{a}}$ & $13 \cdot 8^{\mathrm{b}}$ & $1 \cdot 57$ \\
Acetate & $18 \cdot 8^{\mathrm{a}}$ & $2 \cdot 1^{\mathrm{b}}$ & $0 \cdot 23$ \\
Propionate & $0 \cdot 9^{\mathrm{a}}$ & $4 \cdot 5^{\mathrm{b}}$ & $1 \cdot 15$ \\
Isobutyrate & $7 \cdot 4^{\mathrm{a}}$ & $1 \cdot 0^{\mathrm{b}}$ & $0 \cdot 36$ \\
n-Butyrate & $0 \cdot 2^{\mathrm{a}}$ & $0 \cdot 4^{\mathrm{b}}$ & $0 \cdot 20$ \\
Isovalerate & $0 \cdot 1^{\mathrm{a}}$ & \\
n-Valerate & & \\
\hline
\end{tabular}

a,b Mean values within a row with different superscript letters were significantly different $(P<0.05)$.

* For details of diets and procedures, see Table 1 and pp. 373-376.

exponential component for all three diets. The appearance of enriched $\mathrm{NH}_{3}-\mathrm{N}$ in the right ventral colon and right dorsal colon following a single injection of $\left[{ }^{15} \mathrm{~N}\right]$ urea into the blood is also presented in Fig. 2.

Body urea-N pool size was significantly lower for the horses fed on the $\mathrm{LN}$ diet compared with that of horses fed on diets LNU and LNS. The mean irreversible loss rate of urea-N from plasma was significantly higher for the LNU diet than the LN or LNS diet. Mean irreversible loss rate of urea-N was higher for the LNS diet than the LN diet. Plasma urea$\mathrm{N}$, urea- $\mathrm{N}$ excretion and urea- $\mathrm{N}$ degradation were also significantly different for the three diets and followed a similar pattern to the irreversible loss rate of urea-N. However, the 


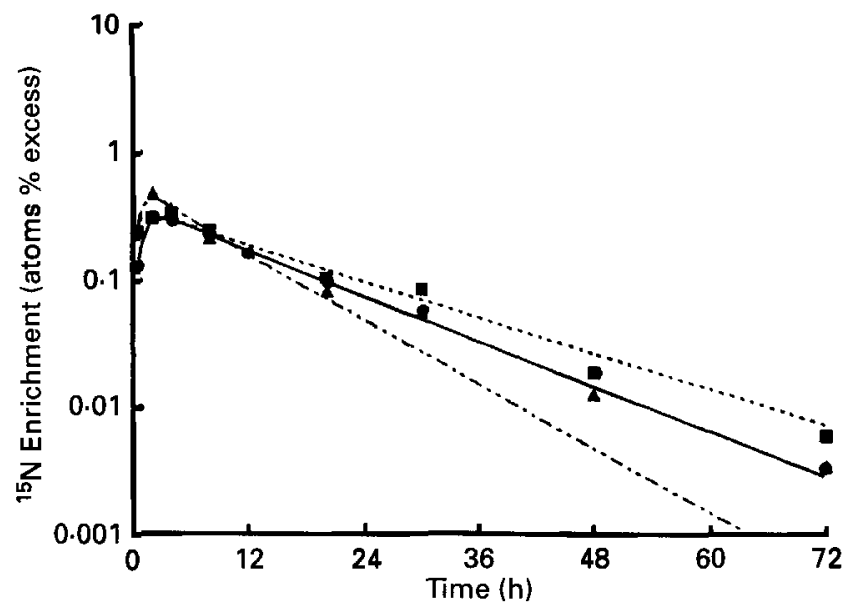

Fig. 1. Intra-gastric $\left[{ }^{15} \mathrm{~N}\right] \mathrm{urea}$ : enrichment of plasma urea-N after a single intragastric dose of $\left[{ }^{15} \mathrm{~N}\right]$ to horse 1 $(\mathrm{O})$, horse $2(\square)$, horse $3(\mathbf{A})$. The lines represent the predicted equations, horse $1(-)$, horse $2(--)$, horse 3 $(--)$ and the symbols are the measurements.

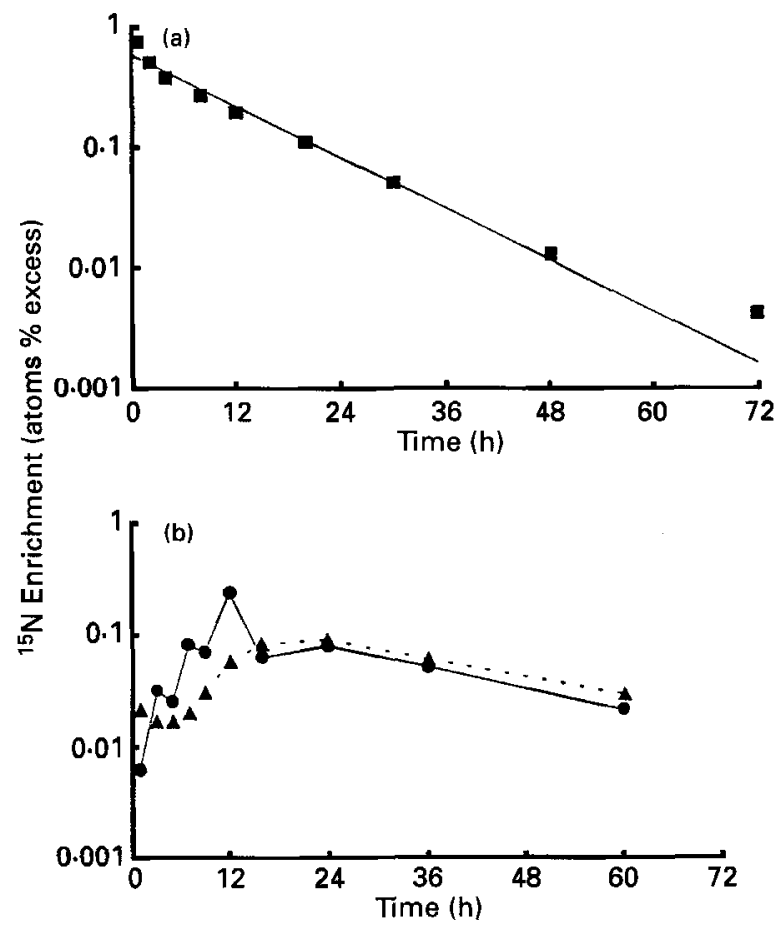

Fig. 2. Injection of $\left[{ }^{15} \mathrm{~N}\right]$ urea into blood. (a) Enrichment of plasma urea-N ( $\square$ ), and (b) ventral colonic ammonia$\mathrm{N}(--)$ and dorsal colonic ammonia- $\mathrm{N}\left(-\mathbf{A}_{-}\right)$after a single injection of $\left[{ }^{15} \mathrm{~N}\right]$ urea into the blood of horse 2 on a low- $\mathrm{N}$ diet. (a) The solid line represents the predicted equation and the symbols are the measurements. (b) The symbols are the measurements and no equation accurately predicted the points measured. 
Table 4. Mean measures of urea metabolism of three horses fed on three different diets estimated using single injections of $\left[{ }^{15} \mathrm{~N}\right]$ urea into the blood*

\begin{tabular}{lcccc}
\hline \hline & \multicolumn{4}{c}{ Diet } \\
\cline { 2 - 5 } Item & LN & LNU & LNS & SD \\
\hline PUN (mmol/l) & $2 \cdot 4^{\mathrm{a}}$ & $7 \cdot 4^{\mathrm{b}}$ & $4 \cdot 9^{\mathrm{c}}$ & $0 \cdot 45$ \\
Body urea-N pool size (g) & $21 \cdot 4^{\mathrm{a}}$ & $56 \cdot 2^{\mathrm{b}}$ & $48 \cdot 5^{\mathrm{b}}$ & $5 \cdot 32$ \\
Body urea space (\% live weight) & 83 & 70 & 90 & $6 \cdot 4$ \\
Urea irreversibly lost (g N/d) & $32 \cdot 6^{\mathrm{a}}$ & $114 \cdot 8^{\mathrm{b}}$ & $85 \cdot 7^{\mathrm{c}}$ & $5 \cdot 33$ \\
Urea excretion (g N/d) & $6 \cdot 4^{\mathrm{a}}$ & $63 \cdot 5^{\mathrm{b}}$ & $46 \cdot 6^{\mathrm{c}}$ & $3 \cdot 46$ \\
Urea degradation (g N/d) & $26 \cdot 1^{\mathrm{a}}$ & $51 \cdot 2^{\mathrm{b}}$ & $39 \cdot 1^{\mathrm{c}}$ & $2 \cdot 72$ \\
Proportion of urea irreversibly lost & $80^{\mathrm{a}}$ & $45^{\mathrm{b}}$ & $46^{\mathrm{b}}$ & $4 \cdot 4$ \\
$\quad$ that enters the GIT (\%) & & & & \\
\hline
\end{tabular}

LN, low nitrogen; LNU, low nitrogen + urea; LNS, low nitrogen + soyabean meal; PUN, plasma urea nitrogen; GIT, gastrointestinal tract.

a,b, Mean values within a row with different superscript letters were significantly different $(P<0 \cdot 05)$.

* For details of diets and procedures, see Table 1 and pp. 374-377.

proportion of urea- $\mathrm{N}$ irreversibly lost that entered the gastrointestinal tract was significantly greater for horses fed on the LN diet than either the LNU or LNS diet. There was no difference between the LNU and LNS diets (Table 4).

Over the $5 \mathrm{~d}$ collection period, 35, 57 and 75 (SD 13.3) \% of the intravenous $\left[{ }^{15} \mathrm{~N}\right]$ urea dose was excreted in urinary $\mathbf{N}(P>0.05)$ and 27,8 and 9 (SD 2.3$) \%$ was excreted in faecal $\mathrm{N}(P<0.05)$ for horses fed on diets LN, LNU and LNS respectively. The percentage of $\left[{ }^{15} \mathrm{~N}\right]$ urea retained after $5 \mathrm{~d}$ of faecal and urinary collection was 38,35 and 15 (SD $11 \cdot 3$ ) \% for horses fed on diets LN, LNU and LNS $(P>0.05)$.

\section{Single injection of $\left[{ }^{15} \mathrm{~N}\right]$ ammonium sulphate into the right ventral colon}

An example of the enrichment of right ventral colonic $\mathrm{NH}_{3}-\mathrm{N}$ with time following single administration of $\left({ }^{15} \mathrm{NH}_{4}\right)_{2} \mathrm{SO}_{4}$ into the right ventral colon is presented in Fig. 3 for diet LNU (horse 1). The ${ }^{15} \mathrm{NH}_{3}$ enrichment-with-time curves in right ventral colonic fluid were best described by equations with two exponential components for all three diets. The appearance of enriched bacterial- $\mathrm{N}$ in the right ventral colon, $\mathrm{NH}_{3}-\mathrm{N}$ and bacterial- $\mathrm{N}$ in the right dorsal colon and plasma urea- $\mathrm{N}$ following administration of $\left({ }^{15} \mathrm{NH}_{4}\right)_{2} \mathrm{SO}_{4}$ into the right ventral colon are also presented in Fig. 3. None of the measures of $\mathrm{NH}_{3}$ metabolism in the right ventral colon differed between diets (Table 5).

The protein precipitates obtained from the plasma samples collected $36 \mathrm{~h}$ after $\left({ }^{15} \mathrm{NH}_{4}\right)_{2} \mathrm{SO}_{4}$ administration into the right ventral colon for each of the three diets were all enriched with ${ }^{15} \mathrm{~N}(0.005$ to 0.01 atoms $\%$ excess).

Over the $5 \mathrm{~d}$ collection period 10,19 and $37(\mathrm{SD} 20.8) \%$ of the $\left({ }^{15} \mathrm{NH}_{4}\right)_{2} \mathrm{SO}_{4}$ dose administered into the right ventral colon was excreted in urinary $\mathrm{N}(P>0.05)$ and 19,12 and 23 (SD 6.6) \% was excreted in faecal N $(P>0.05)$ for horses fed on diets LN, LNU and LNS respectively. The proportion of ${ }^{15} \mathrm{~N}$ retained after $5 \mathrm{~d}$ of faecal and urinary collection was 71, 69 and 40 (SD 27.4) \% for horses fed on diets LN, LNU and LNS $(P>0.05)$.

Rates of transfer of nitrogen between plasma urea and right ventral colonic ammonia pools The mean rates of $\mathrm{N}$ transfer from plasma urea to ventral colonic $\mathrm{NH}_{3}$ did not differ for the three diets (Table 6). There were no significant differences in the mean rates of $\mathrm{N}$ transfer from ventral colonic $\mathrm{NH}_{3}$ to plasma urea between the three diets (Table 6). 


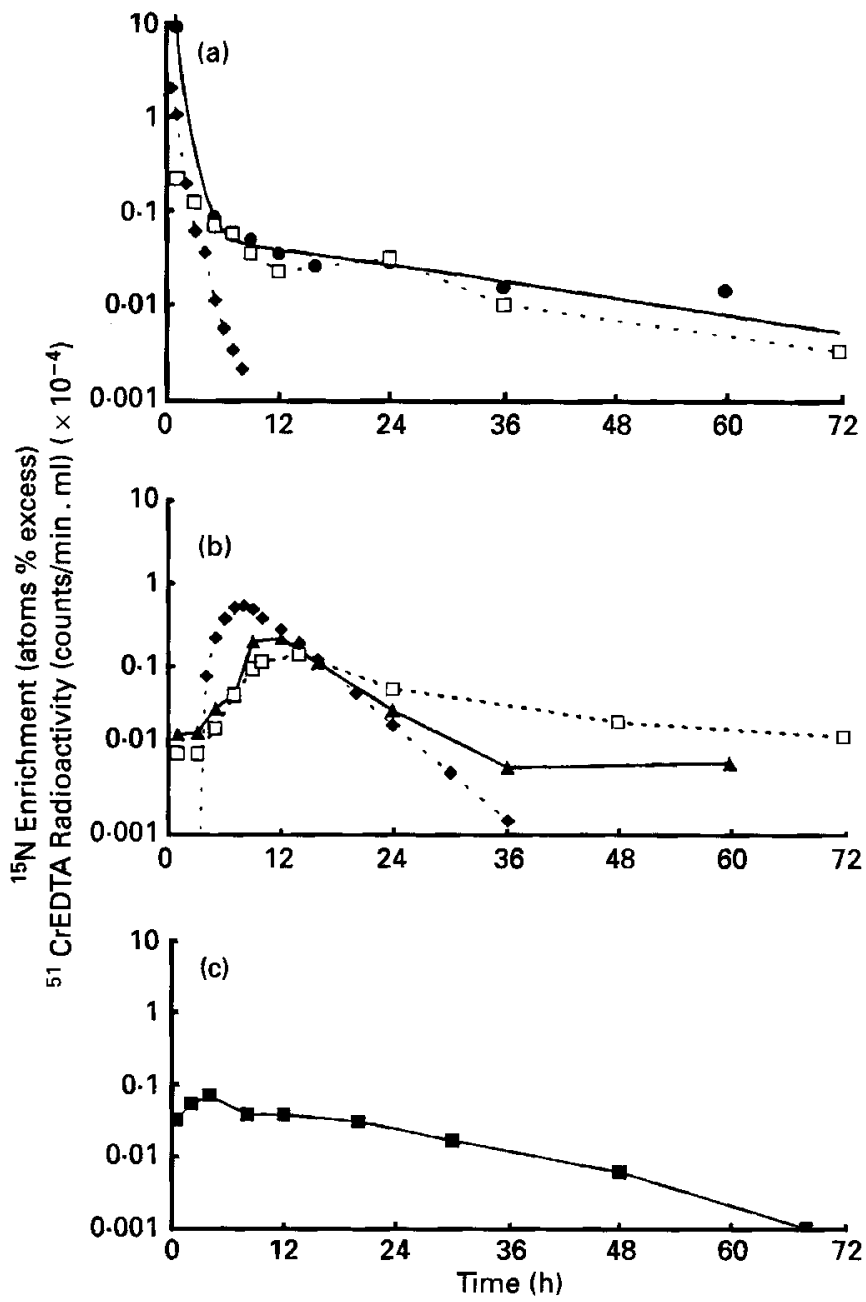

Fig. 3. Injection of $\left({ }^{15} \mathrm{NH}_{4}\right)_{2} \mathrm{SO}_{4}$ and ${ }^{51} \mathrm{CrEDTA}$ into the ventral colon. (a) Enrichment of ventral colonic ammonia-N (O) and bacterial $\mathbf{N}(-\square-)$; (b) dorsal colonic ammonia-N (- $\left.\mathbf{A}^{-}\right)$and bacterial $\mathbf{N}(-\square-)$; (c) plasma urea-N (- -$)$ after a single injection of $\left({ }^{15} \mathrm{NH}_{4}\right)_{2} \mathrm{SO}_{4}$ into the ventral colon of a horse fed on a low- $\mathrm{N}$ diet supplemented with urea. Injection of ${ }^{51} \mathrm{CrEDTA}$ was made simultaneously and its specific radioactivity with time after injection, in the water of the ventral and dorsal colon, is also given (- - ). (a) The solid line represents the predicted equation and the symbols are the measurements. $(b, c)$ The symbols are the measurements and no equation accurately predicted the points measured.

\section{Water kinetics and transit times in the right ventral and dorsal colon}

Although ${ }^{51} \mathrm{CrEDTA}$ was not absorbed from the colon, as negligible radioactivity was detected in urine, first-order kinetics generally did not apply to the disappearance curves of ${ }^{51} \mathrm{Cr}$ in ventral and dorsal colonic fluid. Either instantaneous mixing did not occur and/or recycling of liquid occurred in the pools sampled. It was possible on only two occasions to determine the water volume of the pool sampled in the right ventral colon and right dorsal colon and the outflow of liquid from these sites. It was calculated that the water volumes of the pools sampled in the right ventral colon and right dorsal colon for horse 1 , diet LNU, were 3.7 and 6.8 litres and the outflows of fluid were 95.0 and 34.7 litres/d respectively. The water volumes of the pools sampled in the right ventral colon and right 
Table 5. Mean measures of ammonia metabolism in the right ventral colon of horses fed on three different diets, estimated using single injections of $\left[{ }^{15} \mathrm{~N}\right]$ ammonium sulphate into the right ventral colon, together with right ventral and right dorsal colonic ammonia- $N$ concentrations $(\mathrm{mg} / \mathrm{l})$ and $\mathrm{pH}^{*}$

\begin{tabular}{|c|c|c|c|c|}
\hline \multirow[b]{2}{*}{ Item } & \multicolumn{4}{|c|}{ Diet } \\
\hline & $\begin{array}{l}\text { LN } \\
(n 3)\end{array}$ & $\begin{array}{l}\text { LNU } \\
(n \text { 3) }\end{array}$ & $\begin{array}{l}\text { LNS } \\
(n 2)\end{array}$ & SD \\
\hline Right ventral colonic ammonia- $\mathrm{N}$ pool size $(\mathrm{g})$ & $2 \cdot 7$ & $2 \cdot 0$ & $2 \cdot 0$ & 0.82 \\
\hline Total flux rate of ammonia $(\mathrm{g} \mathrm{N} / \mathrm{d})$ & $66 \cdot 1$ & $42 \cdot 1$ & $55 \cdot 8$ & $16 \cdot 10$ \\
\hline Irreversible loss rate of ammonia ( $\mathrm{g} \mathrm{N} / \mathrm{d}$ ) & $45 \cdot 2$ & $23 \cdot 7$ & $45 \cdot 2$ & 3.43 \\
\hline Recycling rate of ammonia $(\mathrm{g} \mathrm{N} / \mathrm{d})$ & $\begin{array}{l}20 \cdot 9 \\
(n 3)\end{array}$ & $\begin{array}{l}18 \cdot 4 \\
(n 3)\end{array}$ & $\begin{array}{c}10 \cdot 6 \\
(n 3)\end{array}$ & $12 \cdot 65$ \\
\hline Right ventral colonic ammonia- $\mathrm{N}$ & 44 & 53 & 57 & $16 \cdot 8$ \\
\hline Right dorsal colonic ammonia- $\mathrm{N}$ & 159 & 168 & 167 & 6.6 \\
\hline Right ventral colonic $\mathrm{pH}$ & 7.02 & $7 \cdot 03$ & $6 \cdot 99$ & 0.068 \\
\hline Right dorsal colonic $\mathrm{pH}$ & $6 \cdot 80$ & 6.84 & $6 \cdot 90$ & 0.045 \\
\hline
\end{tabular}

LN, low nitrogen; LNU, low nitrogen + urea; LNS, low nitrogen + soyabean meal.

* For details of diets and procedures, see Table 1 and pp. 373-377.

Table 6. Estimates of rates of transfer of nitrogen between plasma urea and right ventral colonic ammonia pools at $24 \mathrm{~h}$ in horses fed on three different diets*

\begin{tabular}{|c|c|c|c|c|c|}
\hline \multirow[b]{2}{*}{ Item } & \multirow[b]{2}{*}{$\begin{array}{l}\text { Injection } \\
\text { site } \dagger\end{array}$} & \multicolumn{4}{|c|}{ Diet } \\
\hline & & $\begin{array}{l}\mathbf{L N} \\
(n 3)\end{array}$ & $\begin{array}{l}\mathrm{LNU} \\
(n 3)\end{array}$ & $\begin{array}{l}\text { LNS } \\
(n 2)\end{array}$ & SD \\
\hline $\begin{array}{l}\text { Plasma urea-N derived from ventral colonic } \\
\text { ammonia-N }(\%)\end{array}$ & RVC & 35 & 14 & 41 & $20 \cdot 4$ \\
\hline $\begin{array}{l}\text { Ventral colonic ammonia-N transferred to plasma } \\
\text { urea- } \mathrm{N}(\mathrm{g} \mathrm{N} / \mathrm{d})\end{array}$ & RVC & $\begin{array}{l}11.9 \\
(n 2)\end{array}$ & $\begin{array}{l}16 \cdot 4 \\
(n 2)\end{array}$ & $\begin{array}{l}33 \cdot 0 \\
(n 2)\end{array}$ & $18 \cdot 37$ \\
\hline $\begin{array}{l}\text { Ventral colonic bacterial } N \text { derived from ventral } \\
\text { colonic ammonia- } N(\%)\end{array}$ & RVC & $\begin{array}{l}45 \\
(n 3)\end{array}$ & $\begin{array}{l}21 \\
(n 2)\end{array}$ & $\begin{array}{l}21 \\
(n 3)\end{array}$ & $18 \cdot 4$ \\
\hline $\begin{array}{l}\text { Ventral colonic ammonia-N derived from plasma } \\
\text { urea-N }(\%)\end{array}$ & IV & $\begin{array}{l}17 \\
(n 3)\end{array}$ & $\begin{array}{l}41 \\
(n 2)\end{array}$ & $\begin{array}{l}18 \\
(n 2)\end{array}$ & 7.0 \\
\hline $\begin{array}{l}\text { Plasma urea-N transferred to ventral colonic } \\
\text { ammonia- } \mathrm{N}(\mathrm{g} / \mathrm{N})\end{array}$ & IV & 8.4 & 11.5 & 10.0 & 5.72 \\
\hline
\end{tabular}

LN, low nitrogen; LNU, low nitrogen + urea; LNS, low nitrogen + soyabean meal.

* For details of diets and procedures, see Table 1 and pp. 373-377.

$\uparrow$ Estimates were computed using dilution values obtained when $\left({ }^{15} \mathrm{NH}_{4}\right)_{2} \mathrm{SO}_{4}$ was administered into the right ventral colon (RVC) or when $\left[{ }^{15} \mathrm{~N}\right]$ urea was administered intravenously (IV).

dorsal colon for horse 2, diet LNS, were 2.9 and 14.6 litres and the outflows of fluid were 91.8 and $56 \cdot 1$ litres/d respectively. There was no retrograde flow from the right dorsal colon to the right ventral colon.

\section{DISCUSSION}

\section{Effectiveness of urea as a dietary supplement}

The results of the present experiment demonstrate that dietary urea offers no nutritional benefit to mature horses consuming low-protein diets. Horses fed on a low-protein diet were able to degrade endogenous urea in the digestive tract. Endogenous urea is likely to 
be important as a $\mathrm{N}$ source for the bacteria, thereby maintaining microbial fermentation in the large intestine and thus providing a supply of VFA to the horses. Although horses fed on the urea-supplemented diet degraded a greater quantity of urea in the digestive tract than did horses fed on the low-N or the soyabean-supplemented diet, this could not compensate for the lack of dietary crude protein.

The horses fed on the low- $\mathrm{N}$ and urea-supplemented diets were in a negative $\mathrm{N}$ balance and all lost weight. Several other studies have reported no improvement in $\mathrm{N}$ retention when urea was added to basal diets containing crude protein concentrations of between 42 and $59 \mathrm{~g} / \mathrm{kg}$ to increase the crude protein concentrations to $91-117 \mathrm{~g} / \mathrm{kg}$ (Reitnour \& Treece, 1971; Johnson \& Hart, 1974; Reitnour, 1978).

\section{Metabolism of ingested urea}

At $5 \mathrm{~d}$ after the administration of intragastric $\left[{ }^{15} \mathrm{~N}\right]$ urea, approximately $26 \%$ of the dose was not accounted for in either faecal or urinary $\mathbf{N}$. It is likely that this unaccounted $\left[{ }^{[5} \mathrm{N}\right]$ urea was degraded to $\mathrm{NH}_{3}$ in the large intestine. This $\mathrm{NH}_{3}$ was probably incorporated into non-essential amino acids in the liver and these amino acids retained in the body as muscle and/or plasma proteins. Schubert et al. (1991) reported that in two lactating pony mares 68 and $72 \%$ of orally administered $\left[{ }^{15} \mathrm{~N}\right]$ urea was excreted in urinary $\mathrm{N}$ and 15 and $7 \%$ in faecal N. Approximately $90 \%$ of the dose was recovered after collecting faeces, urine, milk and body tissues (at slaughter).

\section{Endogenous synthesis and excretion of urea}

The horses fed on the urea-supplemented diet had higher values of urea metabolism than the horses fed on the low-N or the soyabean-supplemented diets. However, although a greater quantity of urea was degraded in the digestive tract of horses fed on the urea- and soyabean-supplemented diets, the percentage of urea lost from the blood that was degraded in the digestive tract was actually lower in these animals than in the horses fed on the low$\mathrm{N}$ diet. Prior et al. (1974) also reported that ponies fed on diets containing $60 \mathrm{~g}$ crude protein $/ \mathrm{kg}$ had lower irreversible loss and degradation rates of urea- $\mathrm{N}$ estimated with $\left[{ }^{14} \mathrm{C}\right]$ urea than did ponies fed on diets containing crude protein levels of $90 \mathrm{~g} / \mathrm{kg}$ or higher. These authors also found that a higher proportion of urea produced in the body was degraded in the digestive tract of horses consuming low-protein diets.

It is logical to expect that, as in other species, some of the urea degraded in the gut would be converted to $\mathrm{NH}_{3}$, absorbed into the blood, reconverted to urea and a proportion recycled back to the gut. The extent of this recycling in the present experiment was so small that statistical analysis failed to detect it even though examination of Fig. 1 suggests that a second decay curve may have been present. Distinguishing between singly- and doublylabelled urea may have detected this recycling.

In the present study the results suggest that renal conservation of $\mathrm{N}$ occurs in horses fed on low-N diets. This is supported by the fact that only $22 \%$ of the intravenous dose of $\left[{ }^{15} \mathrm{~N}\right]$ urea was excreted in urine in a $24 \mathrm{~h}$ period for horses fed on the low- $\mathrm{N}$ diet, whereas 41 and $52 \%$ of the dose was excreted in the same time period for horses fed on the ureaand soyabean-supplemented diets respectively. However, it should be noted that blood urea degraded in the large intestine will only be of value to the horse as a $\mathrm{N}$. source if colonic $\mathrm{NH}_{3}$ is limiting microbial fermentation and growth. In ruminants a similar response to low $\mathrm{N}$ intakes has been observed to those in the present study (Cocimano \& Leng, 1967; Robbins et al. 1974; Bunting et al. 1987). 


\section{Ammonia metabolism in the colon}

In the present study the higher $\mathrm{NH}_{3}-\mathrm{N}$ levels found in the right dorsal colon than those measured in the ventral colon were possibly due to the slow liquid flow rate through the dorsal colon and the accumulation of microbes and their degradation at this site, resulting in release of $\mathrm{NH}_{3}$. Hecker (1971) also reported that the $\mathrm{NH}_{3}-\mathrm{N}$ levels in the left and right dorsal colon were approximately three times higher than those in the left and right ventral colon.

The results obtained concerning $\mathrm{NH}_{3}$ kinetics in the right ventral colon and the rates of $\mathrm{N}$ transfer between pools should be interpreted cautiously. In planning this experiment the assumption was made that instantaneous mixing of $\left({ }^{15} \mathrm{NH}_{4}\right)_{2} \mathrm{SO}_{4}$ would occur in the right ventral colon. However, the results from the dilution curves obtained after the single administration of ${ }^{51} \mathrm{CrEDTA}$ into the right ventral and right dorsal colon indicated that, generally, complete mixing was not instantaneous and/or recycling of liquid occurred. Consequently, the dilution curves for colonic $\mathrm{NH}_{3}-\mathrm{N}$ obtained in this experiment could, in part, be due to movement of $\mathrm{NH}_{3}-\mathrm{N}$ with the colonic fluid within the colon itself.

It is likely that the majority of $\mathrm{N}$ that recycles in the $\mathrm{NH}_{3}-\mathrm{N}$ pool in the right ventral colonic fluid is derived from bacteria that die and are digested in that organ. $\mathrm{NH}_{3}$ could be irreversibly lost from the right ventral colon by incorporation into microbial cells which are transferred to the dorsal colon, by direct absorption through the ventral colonic wall into the portal blood and by loss in colonic fluid which flows to the dorsal colon.

The results of the present study appear to indicate that there was extensive use of non$\mathrm{NH}_{3}-\mathrm{N}$ sources for microbial growth by the microbial population in the ventral colon of the horses. Maczulak et al. (1985) demonstrated that the preferred $\mathrm{N}$ sources of caecal bacteria were peptones and amino acids. In contrast, Glinsky (1976) found that between 42 and $89 \%$ of caecal bacterial $\mathrm{N}$ was derived from caecal $\mathrm{NH}_{3}-\mathrm{N}$.

It was not an objective of the present study to determine if microbial amino acids were absorbed into the circulation. However, it was demonstrated that right ventral colonic $\mathrm{NH}_{3}-\mathrm{N}$ was incorporated into the plasma proteins of each horse fed on each of the three diets. It is quite possible that this was a result of the synthesis of non-essential amino acids in the liver. No mechanism for the active transport of amino acids from the mammalian colon has been demonstrated (Cordero \& Wilson, 1961; Binder, 1970; Munck, 1981).

\section{Flux of urea and ammonia between blood and digestive tract}

The rates of transfer of $\mathrm{N}$ from the plasma urea pool to the right ventral colonic $\mathrm{NH}_{3}$ pool were similar for all three diets. Apparently only 32, 22 and $25 \%$ of the urea- $\mathrm{N}$ that was degraded in the digestive tract entered the right ventral colonic $\mathrm{NH}_{3}-\mathrm{N}$ pool or that proximal to the right ventral colon of horses fed on the low- $\mathrm{N}$, urea-supplemented and soyabean-supplemented diets. Generally similar enrichments of $\mathrm{NH}_{3}-\mathrm{N}$ were noted at the $1 \mathrm{~h}$ sampling time in both the right ventral and the right dorsal colon. This would indicate absorption of endogenous urea along the length of the large intestine.

There appeared to be a greater rate of transfer of $\mathrm{N}$ from the right ventral colonic $\mathrm{NH}_{3}$ pool to the plasma urea pool in horses fed on the soyabean-supplemented diet than in horses fed on the low-N and urea-supplemented diets, although these differences were not significant. This result would appear to make sense as the bacteria in the horses fed on the soyabean-supplemented diet could use other forms of $\mathrm{N}$ (protein). Therefore, the $\mathrm{NH}_{3}$ would not be used as extensively and would be recycled to the plasma. This is supported by the fact that a higher proportion of the $\left({ }^{15} \mathrm{NH}_{4}\right)_{2} \mathrm{SO}_{4}$ dose was excreted in urinary $\mathrm{N}$ of the horses consuming the soyabean-supplemented diet. 


\section{CONCLUSIONS}

Although the quantity of urea degraded in the digestive tract of the horses fed on the ureasupplemented diet was greater than in the horses fed on the low- $N$ or the soyabeansupplemented diet, this increase could not compensate for the lack in dietary crude protein. The horses remained in a negative $\mathrm{N}$ balance and lost as much weight as when they were fed on the low-N diet.

Due to the high proportion of endogenous urea which is degraded in the digestive tract of horses fed on a low-protein diet it would appear that dietary urea supplementation may only be of significant nutritional benefit to horses fed on a protein-free diet or a diet containing a high proportion of essential amino acids but deficient in non-essential amino acids. This situation would not occur under normal grazing conditions.

This project was funded by the Queensland Equine Research Foundation and The University of Queensland Research Grants. The skilled technical assistance of Ms Kelli Gray and Mr Tony Salisbury in the preparation of samples before ${ }^{15} \mathrm{~N}$ analysis is gratefully acknowledged, as is the statistical advice of Mr Doug Bodero.

\section{REFERENCES}

Association of Official Agricultural Chemists (1965). Official Methods of Analysis, 10th ed. Washington, DC: Association of Official Agricultural Chemists.

Binder, H. J. (1970). Amino acid absorption in mammalian colon. Biochimica et Biophysica Acta 219, 503-506.

Bunting, L. D., Boling, J. A., MacKown, C. T. \& Muntifering, R. B. (1987). Effect of dietary protein level on nitrogen metabolism in lambs: studies using ${ }^{15} \mathrm{~N}$-nitrogen. Journal of Animal Science 64, 855-867.

Cocimano, M. R. \& Leng, R. A. (1967). Metabolism of urea in sheep. British Journal of Nutrition 21, 353-371.

Cordero, N. \& Wilson, T. H. (1961). Comparison of transport capacity of small and large intestine. Gastroenterology 41, 500-504.

Cottyn, B. G. \& Boucque, C. V. (1968). Rapid method for the gas-chromatographic determination of volatile fatty acids in rumen fluid. Journal of Agricultural and Food Chemistry 16, 105-107.

Glinsky, M. J. (1976). Volatile fatty acid production and ammonia kinetics in the equine cecum. PhD Thesis, University of Illinois, Urbana-Champaign, IL, USA.

Goering, H. K. \& Van Soest, P. J. (1970). Forage Fibre Analysis, Agriculture Handbook no. 379. Washington, DC: Agriculture Research Service, United States Department of Agriculture.

Hecker, J. F. (1971). Ammonia in the large intestine of herbivores. British Journal of Nutrition 26, 135-145.

Houpt, T. R. \& Houpt, K. A. (1971). Nitrogen conservation by ponies fed a low-protein ration. American Journal of Veterinary Research 32, 579-588.

Johnson, R. J. \& Hart, J. W. (1974). Utilization of nitrogen from soybean meal, biuret and urea by equine. Nutrition Reports International 9, 209-216.

Maczulak, A. E., Dawson, K. A. \& Baker, J. P. (1985). Nitrogen utilization in bacterial isolates from the equine cecum. Applied and Environmental Microbiology 50, 1439-1443.

Mills, S. E., Armentano, L. E., Russell, R. W. \& Young, J. W. (1981). Rapid and specific isolation of radioactive glucose from biological samples. Journal of Dairy Science 64, 1719-1723.

Munck, G. (1981). Intestinal absorption of amino acids. In Physiology of the Gastrointestinal Tract, pp. 1097-1122 [L. R. Johnson, editor]. New York: Raven Press.

National Research Council (1978). Nutrient requirements of horses. In Nutrient Requirements of Domestic Animals, 4th ed. Washington, DC: National Academy of Sciences-National Research Council.

National Research Council (1989). Nutrient requirements of horses. In Nutrient Requirements of Domestic Animals. 5th ed. Washington, DC: National Academy of Sciences-National Research Council.

Nolan, J. V. \& Leng, R. A. (1972). Dynamic aspects of ammonia and urea metabolism in sheep. British Journal of Nutrition 27, 177-194.

Prior, R. L., Hintz, H. F., Lowe, J. E. \& Visek, W. J. (1974). Urea recycling and metabolism of ponies. Journal of Animal Science 38, 565-571.

Reitnour, C. M. (1978). Response to dietary nitrogen in ponies. Equine Veterinary Journal 10, 65-68.

Reitnour, C. M. \& Treece, J. M. (1971). Relationship of nitrogen source to certain blood components and nitrogen balance in the equine. Journal of Animal Science 32, 487-490.

Robbins, C. T., Prior, R. L., Moen, A. N. \& Visek, W. J. (1974). Nitrogen metabolism of white-tailed deer. Journal of Animal Science 38, 186-191. 
Schubert, R., Zander, R., Gruhn, K. \& Hennig, A. (1991). First results on the incorporation and excretion of ${ }^{15}$ N from orally administered urea in lactating pony mares. Archives of Animal Nutrition 41, 457-463.

Simmons, H. A. \& Ford, E. J. H. (1988). Multiple cannulation of the large intestine of the horse. British Veterinary Journal 144, 449-454.

White, R. G., Steel, J. W., Leng, R. A. \& Luick, J. R. (1969). Evaluation of three isotope-dilution techniques for studying the kinetics of glucose metabolism in sheep. Biochemical Journal 114, 203-214. 